\title{
Risk Factors for Obstructive Sleep Apnea Syndrome in Children: State of the Art
}

\author{
Giampiero Gulotta ${ }^{1}$, Giannicola Iannella ${ }^{1,2, * \mathbb{D}}$, Claudio Vicini ${ }^{2,3}$, Antonella Polimeni ${ }^{4}$, \\ Antonio Greco ${ }^{1}$, Marco de Vincentiis ${ }^{1}$, Irene Claudia Visconti ${ }^{1}$, Giuseppe Meccariello ${ }^{2}$, \\ Giovanni Cammaroto ${ }^{2}$, Andrea De Vito ${ }^{2} \oplus$, Riccardo Gobbi ${ }^{2}$, Chiara Bellini ${ }^{2}$, Elisabetta Firinu ${ }^{2}$, \\ Annalisa Pace ${ }^{1}$, Andrea Colizza ${ }^{1}{ }^{1}$, Stefano Pelucchi ${ }^{3}$ and Giuseppe Magliulo ${ }^{1}$ \\ 1 Department of “Organi di Senso", University "Sapienza”, 00185 Rome, Italy \\ 2 Department of Head-Neck Surgery, Otolaryngology, Head-Neck and Oral Surgery Unit, \\ Morgagni Pierantoni Hospital, 47121 Forlì, Italy \\ 3 Ear-Nose-Throat \& Audiology Unit, University of Ferrara, 44121 Ferrara, Italy \\ 4 Department of Oral and Maxillo Facial Sciences, University “Sapienza", 00185 Rome, Italy \\ * Correspondence: giannicola.iannella@uniroma1.it; Tel.: +39-32-8789-3753
}

Received: 24 June 2019; Accepted: 25 August 2019; Published: 4 September 2019

check for updates

\begin{abstract}
The obstructive sleep apnea syndrome (OSAS) represents only part of a large group of pathologies of variable entity called respiratory sleep disorders (RSD) which include simple snoring and increased upper airway resistance syndrome (UARS). Although the etiopathogenesis of adult OSAS is well known, many aspects of this syndrome in children are still debated. Its prevalence is about $2 \%$ in children from 2 to 8 years of age, mostly related to the size of the upper airways adenoid tissue. Several risk factors linked to the development of OSAS are typical of the pediatric age. The object of this paper is to analyze the state of the art on this specific topic, discussing its implications in terms of diagnosis and management.
\end{abstract}

Keywords: pediatric OSAS; obesity; adenotonsillar hypertrophy; craniofacial abnormalities; allergic rhinitis; inflammation

\section{Introduction}

Respiratory sleep disorders (RSD) in children are characterized by a variable obstruction of the upper airway and different degrees of alteration in gas exchange during the night [1,2].

The third edition of the International Classification of Sleep Disorders (ICSD-3) defines OSAS as a polysomnography (PSG)-determined obstructive respiratory disturbance index (RDI) $\geq 5$ events/h associated with the typical symptoms of OSAS (e.g., unrefreshing sleep, daytime sleepiness, fatigue or insomnia, awakening with a gasping or choking sensation, loud snoring, or witnessed apneas), or an obstructive RDI $\geq 15$ events/h (even in the absence of symptoms) [3]. In addition to the apneas and hypopneas that are included in the Apnea-Hypopnea Index (AHI), the RDI includes respiratory effort-related arousals (RERAs). The scoring of respiratory events is defined in the AASM Manual for the Scoring of Sleep and Associated Events: Rules, Terminology and Technical Specifications, Version 2.3 (AASM Scoring Manual) [4]. However, some variability in the definition of a hypopnea event should be noted.

According to the AASM Scoring Manual recommended definition, changes in flow should be associated with a $3 \%$ oxygen desaturation or a cortical arousal, although an alternative definition that requires association with a $4 \%$ oxygen desaturation without consideration of cortical arousals is accepted. Depending on which definition is used, the AHI may be considerably different in any given 
individual [5-7]. The discrepancy between these and other hypopnea definitions used in research studies makes the evaluation of evidence regarding the diagnosis of OSAS a complex matter.

The apnea-hypopnea index (AHI) is the average number of disordered breathing events per hour. Typically, the OSA syndrome is defined as an AHI of 5 or greater. An AHI of $5-15$ is considered as mild, 15-30 is moderate and more than 30 events per hour characterizes severe sleep apnea.

The precise incidence of OSAS in adults is still unknown. It is estimated that 24 percent of men and 9 percent of women have the breathing symptoms of OSAS with or without daytime sleepiness, but about 80 percent of adults with OSAS remain undiagnosed [8].

On the other hand, respiratory sleep disorders (RSD) in children are characterized by a variable obstruction of the upper airway and different degrees of alteration in gas exchange during the night.

The clinical presentation goes from habitual snoring to complete obstruction of the airway $[9,10]$. The European Respiratory Society (ERS) taskforce for the diagnosis and management of obstructive RSD in childhood defines OSAS as "a syndrome of upper airway dysfunction during sleep, characterized by snoring and/or increased respiratory effort secondary to increased upper airway resistance and pharyngeal collapsibility" [11]. In childhood OSAS there is not a clear correlation between the severity of the clinical presentation and daytime symptoms, with a more nuanced range of symptoms [12].

Gozal et al. [13] proposed several criteria, classified into major and minor, for the diagnosis of OSAS in children and, above all, to assess the need for treatment. The major ones include an AHI $>2$, RDI $>2$, Nadir SpO2 $<90 \%$, excessive daytime sleepiness, academic difficulties, hyperactive behavior, hypertension, enuresis, and obesity. Among the minor ones, there are high levels of CRP, LDL, fasting insulin and low levels of HDL, recurrent middle ear otitis and adenotonsillar grade $>1$. The positivity of five major criteria, or three major criteria plus 3 minor criteria, indicates the need for therapeutic procedures.

According to latest guidelines, the general incidence of OSAS in the pediatric population is about $2 \%$ [9]. Most children are around 2-8 years of age, due to the relative size of the lymphatic tissue of the upper airways [14]. OSAS is more common in males than females. African Americans and obese children are both at increased risk for OSAS [15]. While many studies have addressed the etiopathogenesis of adult OSAS, many aspects of this syndrome in children remain unclear. However, there are many risk factors which can lead to a reduction or collapse of the upper airways and which may contribute to the pathogenesis of OSAS.

The diagnosis of pediatric OSAS include a detailed clinical history, focusing on physical findings, especially in the ENT district, nocturnal and diurnal symptoms and comorbidities followed by specific questionnaires administered to parents. Nocturnal oximetry and ambulatory polysomnography are mandatory. In patients with residual OSAS after surgery, DISE should be considered to detect the anatomical site of potential collapse.

To our knowledge, few papers have been published on the risk factors linked to OSAS, especially in the pediatric age $[9,16]$. We were able to find out 182 articles from 2012 to 2019 on Pubmed and MEDLINE using the keywords "Risk factors; Pediatric OSAS; Obesity; Adenotonsillar hypertrophy; Craniofacial abnormalities; Allergic rhinitis; Inflammation". Only 123 articles discussed this specific topic in children. Furthermore, it should be noted that the majority of the papers analyzed only one single risk factor and rarely multiple factors, focusing essentially on the overview of the OSAS. The very exhaustive papers published by Marcus C.L. et al. [9] and Li Z. et al. [16] are typical examples of this observation. They made a general, wonderful presentation of the pathology, but dedicated just a few paragraphs in evaluating the various risk factors.

Thus, the aim of this paper is devoted to analyzing the state of the art on this specific and its impact on diagnosis and treatment. 


\section{Risk Factors}

\subsection{Obesity}

Obesity is one of the most important risk factors for OSAS in both the adult and pediatric populations.

Obesity affects OSAS mainly through two mechanisms: The presence of fat at the level of the pharyngeal soft tissue reduces the caliber of the lumen and increases the collapse of the structures themselves. Secondly, the increased presence of fat in the thoracic and abdominal walls significantly reduces respiratory function in these patients $[17,18]$.

Each increment in body mass index (BMI) above the 50th percentile is associated with around a $10 \%$ increased risk for OSAS [19].

From 1975 to 2016, the mean BMI in children and adolescents increased globally, up to $18.6 \mathrm{~kg} / \mathrm{m}^{2}$ (18.4-18.7) for girls and $18.5 \mathrm{~kg} / \mathrm{m}^{2}$ (18.3-18.7) for boys in 2016. Moreover, childhood obesity is not only a widespread phenomenon, but also a persistent one: About $50 \%$ of obese children are also likely to be obese adults [20].

Overweight or obese children have a higher risk of developing OSAS compared with normalweighted children [21].

Even though adenotonsillectomy (AT) represents the first line therapy for these children, several studies have reported that obesity increases the risk of persistent OSAS after surgery [22-25]. To this regard $\mathrm{Xu} \mathrm{Z}$. et al. reported a direct correlation between the body mass index standard deviation score (BMI SDS) and the apnea-hypopnea index (AHI) [26].

Weight-loss management could be the key in the treatment of obesity-related OSAS in children and adolescents; specially in those that have previously performed adeno-tonsillectomy surgery without clinical results. Despite many studies supported weight-loss management as a key point therapy for OSAS in obese adults, only a few have studied the effect of obesity treatment on childhood OSA [27-29]. Andersen I.G. et al. [30] conducted a prospective longitudinal study on a population of 62 children and adolescents treated in a chronic care multidisciplinary overweight- and obesity treatment clinic. They observed a normalization of AHI in 38\% of them after 6 months of obesity treatment and in $44 \%$ after one year of weight-loss.

These evidence lead us to consider weight-loss as first line therapy for these children with elevated BMI.

Studies that have analyzed obesity as pediatric OSAS risk factor are reported in Table 1.

Table 1. Studies that have analyzed obesity as a pediatric OSA risk factor.

\begin{tabular}{|c|c|c|c|c|c|c|}
\hline Study & Year & Type of Study & $\begin{array}{l}\text { Patients } \\
\text { Number }\end{array}$ & Age & $\begin{array}{l}\text { Parameters } \\
\text { Evaluated }\end{array}$ & Conclusions \\
\hline $\begin{array}{c}\text { Arens R et al. } \\
\text { [18] }\end{array}$ & 2018 & $\begin{array}{l}\text { Case-control } \\
\text { study }\end{array}$ & 44 & $12.5 \pm 2.8$ & $\begin{array}{l}\text { Anatomical findings } \\
\text { in obese children } \\
\text { affected by OSAS } \\
\text { compared to the ones } \\
\text { in obese children }\end{array}$ & $\begin{array}{l}\text { Significant upper airway } \\
\text { lymphoid hypertrophy in } \\
\text { obese children with OSAS. } \\
\text { Larger parapharyngeal fat } \\
\text { in obese children with } \\
\text { OSAS but not a direct } \\
\text { association with severity of } \\
\text { OSAS or with obesity }\end{array}$ \\
\hline $\begin{array}{l}\text { Su M. et al. } \\
\text { [21] }\end{array}$ & 2016 & $\begin{array}{l}\text { Epidemiological } \\
\text { study }\end{array}$ & 5930 & 3-11 & $\begin{array}{c}\text { Age and sex; } \\
\text { AHI; } \\
\text { Arousal index; } \\
\text { BMI; } \\
\text { Mallampati; } \\
\text { AT hypertrophy; } \\
\text { Nocturnal/daytime } \\
\text { symptoms }\end{array}$ & $\begin{array}{l}\text { No positive correlation } \\
\text { between OSA and BMI }\end{array}$ \\
\hline
\end{tabular}


Table 1. Cont.

\begin{tabular}{|c|c|c|c|c|c|c|}
\hline Study & Year & Type of Study & $\begin{array}{l}\text { Patients } \\
\text { Number }\end{array}$ & Age & $\begin{array}{l}\text { Parameters } \\
\text { Evaluated }\end{array}$ & Conclusions \\
\hline $\begin{array}{l}\text { Xu Z. et al. } \\
\text { [26] }\end{array}$ & 2008 & $\begin{array}{l}\text { Case-control } \\
\text { Study }\end{array}$ & 198 & $10.3 \pm 2.1$ & $\begin{array}{c}\text { Age and sex; } \\
\text { BMI; } \\
\text { Waist circumference; } \\
\text { Neck circumference; } \\
\text { Waist-to-Height Ratio; } \\
\text { Symptoms; } \\
\text { AHI, Obstructive } \\
\text { Apnea Index, Central } \\
\text { Apnea, MinSaO2; } \\
\text { AT hypertrophy }\end{array}$ & $\begin{array}{l}\text { Positive relation between } \\
\text { OSAS and degree of obesity }\end{array}$ \\
\hline $\begin{array}{c}\text { Andersen } \\
\text { I.G. et al. } \\
\text { [30] }\end{array}$ & 2019 & $\begin{array}{l}\text { Longitudinal } \\
\text { study }\end{array}$ & 62 & $13.4 \pm 3.1$ & $\begin{array}{c}\text { Age and sex; } \\
\text { BMI; } \\
\text { AT hypertrophy; } \\
\text { AHI; } \\
\text { Sleep time (hours); } \\
\text { ODI }\end{array}$ & $\begin{array}{l}\text { AHI normalization in } 44 \% \\
\text { of patients and positive } \\
\text { correlation between BMI } \\
\text { and AHI parameters }\end{array}$ \\
\hline
\end{tabular}

\subsection{Adenoid and/or Tonsil Hypertrophy}

The lymphoid tissue of the Waldeyer ring is more developed at an age between 3 and 6 years, according to the peak incidence of OSAS [31,32]. Adenoid and/or tonsil hypertrophy are the most common causes of upper airway lumen reduction in children, evaluated by the Friedman Grading Scale (Table 2).

Table 2. Reproducibility of clinical grading of tonsillar size.

\begin{tabular}{cc}
\hline Grade & Description \\
\hline 0 & No tonsils seen \\
I & In tonsillar fossa \\
II & Visible beyond anterior pillars \\
III & Extended $\frac{3}{4}$ of way to midline \\
IV & Completely obstructing airway (kissing tonsils) \\
\hline
\end{tabular}

Adenotonsillar hypetrophy contributes to the narrowing of the retro-palatal area, which has the smallest cross-sectional area and is therefore the most frequent site of obstruction, as shown in a 6 years old patient in Figure 1. In particular, children with Grade IV tonsils (kissing tonsils) are very susceptible to developing sleep disorders, due to oropharyngeal narrowing and lateral collapse.

Adenotonsillar hypertrophy leads to mouth breathing, nasal congestion, hyponasal speech, snoring, chronic sinusitis, and recurrent otitis media, as well as poor brain development and emotional disturbances. Kurnatowski P. et al. [33] in their study of six- to nine-year-old children reported high scores of emotional instability in the adenotonsillar hypertrophy group, compared to healthy controls, with good results on the behavior of most of the children 3-10 months after surgery. Some authors highlighted the role of inflammation in the development of adenotonsillar hypertrophy and OSAS, given the increased expression of various mediators of inflammatory responses in the tonsils and improvement following treatment with anti-inflammatory agents such as corticosteroids, suggesting a multi-disciplinary approach for treatment. 


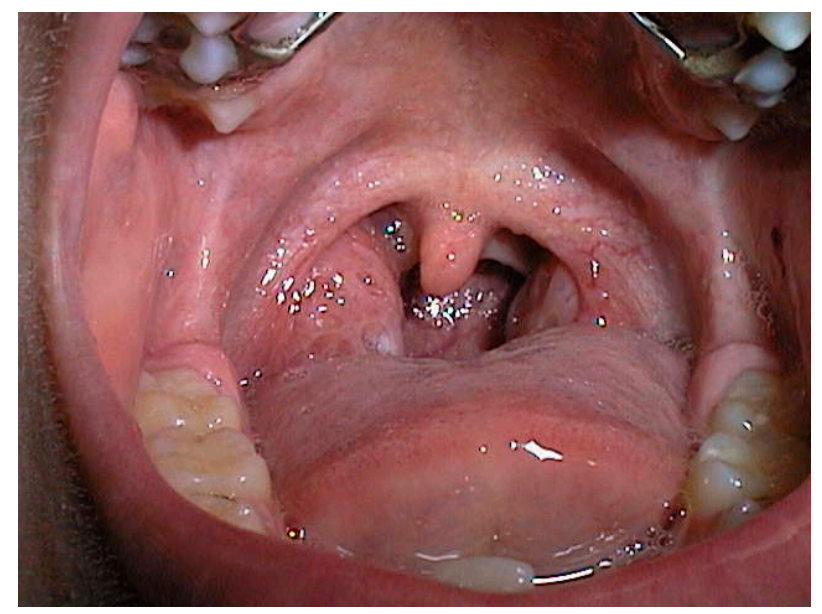

Figure 1. Grade III tonsil hypertrophy in a 6 year-old child. Courtesy of Professor C. Vicini-Department of Head-Neck Surgery, Otolaryngology, Head-Neck and Oral Surgery Unit, Morgagni Pierantoni Hospital, Forlì, Italy.

The gold standard of surgical treatment is represented by adenotonsillectomy [9,34]. Brietzke et al. [34] demonstrated the resolution of the polysomnographic findings in $83 \%$ of children with OSAS without other co-morbidities. Several recent studies have confirmed the efficacy but have suggested long-term follow up, especially in children with concomitant comorbidities, in order to avoid residual OSAS [35,36]. On the other hand, in the adult OSAS population, tonsillectomy is more often associated with palatal surgery. However, Senchak AJ et al. [37] proposed tonsillectomy as isolated surgery. They enrolled 202 subjects. The AHI before surgery ranged from 5.4 to 56.4 events per hour. The mean AHI decreased from 18 to 3.2 events per hour, a reduction of $82 \%$. Following tonsillectomy alone, there were statistically significant reductions in median RDI and in the Epworth Sleepiness Scale (ESS) and Berlin scores. They drew the conclusion that adult tonsillectomy alone could be effective, especially in young overweight men with large tonsils, moderate OSAS and low Friedman stage.

Recent studies have also suggested the role of lingual tonsil hypertrophy in the pathogenesis of pediatric OSAS, as frequent evidenced in the adult population [8-12]. Figure 2 shows lingual hypertrophy in a 11-year-old child. In adults, the procedure of reducing lingual tonsil through Trans Oral Robotic Surgery (TORS) is widely used. In children, it is not a common procedure [38,39]. In particular, the young patient of Figure 3 underwent robotic surgery due to severe OSAS with disabling symptoms without adenotonsillar hypertrophy or other risk factors.

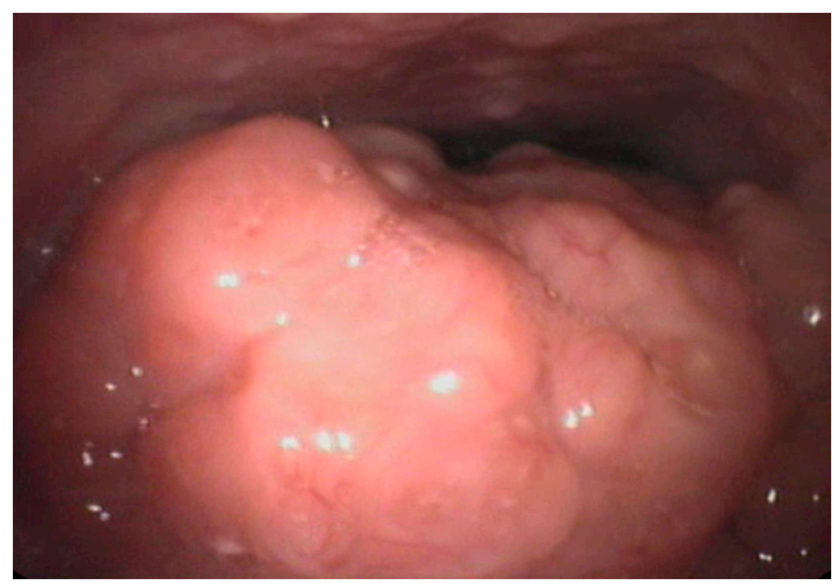

Figure 2. Lingual tonsil hypertrophy in a 11 year-old child. Courtesy of Professor C. Vicini-Department of Head-Neck Surgery, Otolaryngology, Head-Neck and Oral Surgery Unit, Morgagni Pierantoni Hospital, Forlì, Italy. 


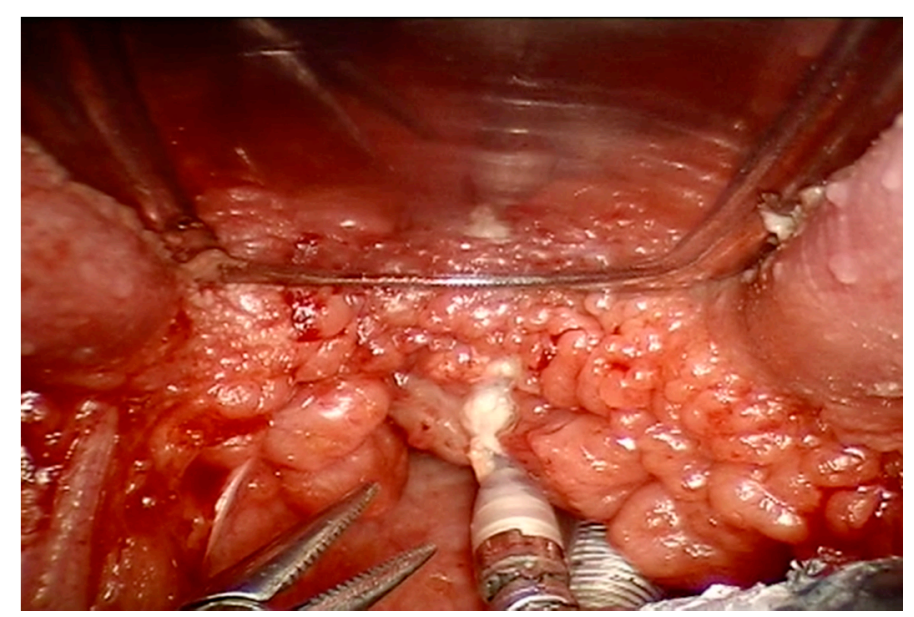

Figure 3. Transoral robotic surgery (TORS) to remove an exuberant lingual tonsil in a 12-year-old child. Courtesy of Professor C. Vicini-Department of Head-Neck Surgery, Otolaryngology, Head-Neck and Oral Surgery Unit, Morgagni Pierantoni Hospital, Forlì, Italy.

The possibility of intracapsular tonsillotomy using Debrider or Coblation should be considered in this type of surgery in order to remove only the exuberant lymphatic tissue of tonsils. Reported similar intracapsular tonsillotomy seems to show similar results in terms of AHI reduction with respect classical extracapsular tonsillectomy with a lower risk of postoperative bleeding [40].

Supraglottoplasty in cases of laryngomalacia associated with exuberant arytenoid tissue or epiglottoplasty in case of epiglottis hypertrophy/instability, are possible treatment options and should always be considered [37,38].

Midline posterior glossectomy is less frequently performed in pediatric OSAS patients [41].

Studies that have analyzed adenoid and/or tonsil hypertrophy as a pediatric OSAS risk factor have been reported in Table 3 .

Table 3. Studies that have analyzed adenoid and/or tonsil hypertrophy as a pediatric OSAS risk factor.

\begin{tabular}{|c|c|c|c|c|c|c|}
\hline Study & Year & Type of Study & $\begin{array}{l}\text { Patients } \\
n^{\circ}\end{array}$ & Age & Parameters Evaluated & Conclusions \\
\hline $\begin{array}{l}\text { Kurnatowski } \\
\text { P. et al. [33] }\end{array}$ & 2007 & $\begin{array}{l}\text { Case-control } \\
\text { study }\end{array}$ & 225 & $10-13$ & $\begin{array}{c}\text { Age and sex; } \\
\text { Total sleep time; } \\
\text { AHI, ODI; } \\
\text { AT grade sec. Friedman; } \\
\text { Spielberger test; } \\
\text { Capra and Pastorelli scale }\end{array}$ & $\begin{array}{l}\text { Negative emotional } \\
\text { effect of adenotonsillar } \\
\text { hypertrophy } \\
\text { induced obstructive } \\
\text { sleep disordered } \\
\text { breathing }\end{array}$ \\
\hline $\begin{array}{l}\text { Brietzke S.E. } \\
\text { et al. [34] }\end{array}$ & 2006 & $\begin{array}{c}\text { Meta-analysis } \\
\text { (14 studies) }\end{array}$ & $\begin{array}{c}28 \\
\text { (mean) }\end{array}$ & $\begin{array}{c}4.9 \text { (pooled } \\
\text { mean age) }\end{array}$ & $\begin{array}{c}\text { Age; } \\
\text { Pre AT AHI; } \\
\text { Post AT AHI; } \\
\text { Success of AT; }\end{array}$ & $\begin{array}{c}\text { AT effective in reducing } \\
\text { severity of OSAS in } \\
\text { majority of patients }\end{array}$ \\
\hline $\begin{array}{l}\text { Kang K.T. et } \\
\text { al. [38] }\end{array}$ & 2017 & $\begin{array}{c}\text { Meta-analysis } \\
\text { (4 studies) }\end{array}$ & $\begin{array}{l}18.25 \\
\text { (mean) }\end{array}$ & $\begin{array}{c}8.3 \pm 1.1 \\
(\text { mean })\end{array}$ & $\begin{array}{c}\text { Age; } \\
\text { BMI; } \\
\text { Other comorbidities; } \\
\text { CT, RMN, DISE; } \\
\text { Preoperative AHI; } \\
\text { Postoperative AHI } \\
\text { Preoperative ODI; } \\
\text { Postoperative ODI }\end{array}$ & $\begin{array}{l}\text { Effectiveness of lingual } \\
\text { tonsillectomy for } \\
\text { children with OSA } \\
\text { caused by lingual tonsil } \\
\text { hypertrophy }\end{array}$ \\
\hline $\begin{array}{l}\text { Lee C.F. et al. } \\
\text { [41] }\end{array}$ & 2016 & $\begin{array}{c}\text { Meta-analysis } \\
\text { (11 studies) }\end{array}$ & $\begin{array}{c}11 \\
\text { (mean) }\end{array}$ & 3.7 (mean) & $\begin{array}{c}\text { Age; } \\
\text { BMI; } \\
\text { Preoperative AHI; } \\
\text { Postoperative AHI } \\
\text { Preoperative ODI; } \\
\text { Postoperative ODI }\end{array}$ & $\begin{array}{l}\text { Effectiveness in } \\
\text { reducing } \mathrm{AHI} \text { and } \\
\text { MinSaO2, but complete } \\
\text { resolution not achieved } \\
\quad \text { in most cases }\end{array}$ \\
\hline
\end{tabular}




\subsection{Allergic Rhinitis}

It is believed that allergic rhinitis (AR) can affect sleep through different mechanisms. Nasal congestion secondary to the nasal mucosa inflammatory process induces increased airway resistance and may result in oral breathing, sleep disruption, and fatigue [42].

Nasal patency is mainly regulated by the capacitance vessels of the middle and inferior turbinates [43]. What happens in an allergic patient is an increased nasal resistance with dilatation of these capacitance vessels, with mucosal edema and mucous secretions [44]. The most common symptoms of allergic rhinitis patients are rhinorrhea, nasal blockage or congestion, and stuffy nose. Clearly, nasal obstruction is also associated with olfactory disorders because of the reduction of odourants that enter the nose during breathing $[45,46]$.

Further exacerbating airflow limitation, an increase in airflow velocity may cause paradoxical airway narrowing in the nasal valve and, as the obstruction progresses, in the oropharynx too.

Lofaso et al. [47] used posterior rhinomanometry to highlight the correlation between nasal obstruction and OSAS severity, independently of other risk factors. They evaluated 541 unselected consecutive snorers referred for suspected breathing disorders during sleep over a 2 year period. In addition, cephalometric landmarks and body mass index (BMI) were obtained. Polysomnography was used to determine the number of abnormal respiratory events that occurred during sleep. They concluded that permanent physical nasal obstruction unresponsive to nasal decongestants, and functional nasal obstruction responsive to nasal decongestants, such as those that occur during vasomotor rhinitis, may contribute to sleep-disordered breathing. and is an independent risk factor for OSAS.

McNicholas WT [48] et al. demonstrated longer and more frequent obstructive apneas in patients with allergic rhinitis to ragweed, especially during the ragweed season rather than after the pollen season [47]. Furthermore, an elevated Mallampati score seems to have a synergistic effect in these patients.

Liistro et al. [49] proposed a two-hit phenomenon, with a higher relative risk for OSA in those with a reduced posterior pharynx space due to tongue base hypertrophy and nasal obstruction, compared to those with only one of these risk factors.

Additionally, inflammatory mediators of the allergic process, such as histamine and certain cytokines, may act directly on the central nervous system by altering sleep rhythm. It has been recently observed in children with sleep disorders, that the presence of allergic rhinitis (without obstructive sleep apnea) decreases REM (Rapid Eye Movement) sleep time [50]. A recent meta-analysis from Cao Y. et al. [51] evaluated the association between allergic rhinitis and obstructive sleep apnea in both adult and pediatric population. They included 44 studies, comprising 6086 participants. They reported an incidence of children diagnosed with AR 2.12 times higher in OSA/RSD patients. However, the same trend was not found in the adult population. The possible cause is related to the immaturity of the immune system in children. Medical treatment, such as nasal steroids and oral montelukast has been studied as a treatment option for OSAS children with concomitant allergic rhinitis and asthma. Kheirandish-Gozal et al. [52] described an overall success rate of $80 \%$ in children aged 2-14 years using intranasal steroid therapy and oral montelukast. The same group recently compared the effect of 16 weeks of oral montelukast therapy with placebo for treatment of childhood OSAS with good results [53].

More recently, the American Academy of Pediatrics stated that nasal steroid therapy is indicated for children with mild OSAS who cannot undergo surgery or for those with persisting residual OSAS after surgery [54].

Studies that have analyzed allergic rhinitis as a pediatric OSA risk factor have been reported in Table 4 . 
Table 4. Studies that have analyzed allergic rhinitis as a pediatric OSA risk factor.

\begin{tabular}{|c|c|c|c|c|c|c|}
\hline Study & Year & Type of Study & $\begin{array}{l}\text { Patients } \\
n^{\circ}\end{array}$ & Age & Parameters Evaluated & Conclusions \\
\hline $\begin{array}{l}\text { Cao Y. et al. } \\
\text { [51] }\end{array}$ & 2018 & $\begin{array}{l}\text { Meta-analysis } \\
\text { (44 studies) }\end{array}$ & $\begin{array}{l}6086 \\
\text { total } \\
\text { patients }\end{array}$ & $\begin{array}{c}47.97 \\
\text { (adults) } \\
7.73 \\
\text { (children) }\end{array}$ & $\begin{array}{c}\text { Age and Sex; } \\
\text { BMI; } \\
\text { Neck circumference; } \\
\text { AHI; } \\
\text { ESS; } \\
\text { AR prevalence }\end{array}$ & $\begin{array}{c}\text { Children with OSA } \\
\text { suffering from a higher } \\
\text { incidence of AR. OSA } \\
\text { adults with AR do not } \\
\text { have any influences on } \\
\text { sleep parameters }\end{array}$ \\
\hline $\begin{array}{l}\text { Kheirandish- } \\
\text { Gozal L. et } \\
\text { al. [52] }\end{array}$ & 2014 & $\begin{array}{l}\text { Retrospective } \\
\text { review }\end{array}$ & 3071 & $2-14$ & $\begin{array}{c}\text { Age and Sex; } \\
\text { BMI; } \\
\text { Pretreatment: AT grade; } \\
\text { Mallampati; } \\
\text { Total sleep time; } \\
\text { AHI, ODI; } \\
\text { Posttreatment: } \\
\text { Pretreatment: AT grade; } \\
\text { Mallampati; } \\
\text { Total sleep time; } \\
\text { AHI, ODI }\end{array}$ & $\begin{array}{l}\text { Effective alternative to } \\
\text { adenotonsillectomy, } \\
\text { particularly in younger } \\
\text { and non-obese } \\
\text { Children }\end{array}$ \\
\hline $\begin{array}{l}\text { Kheirandish- } \\
\text { Gozal L. et } \\
\text { al. [53] }\end{array}$ & 2016 & $\begin{array}{l}\text { Prospective } \\
\text { randomized } \\
\text { trial study }\end{array}$ & 92 & $2-10$ & $\begin{array}{c}\text { Age and Sex; } \\
\text { BMI; } \\
\text { Pretreatment: AT grade; } \\
\text { Mallampati; } \\
\text { Total sleep time; } \\
\text { AHI, ODI; } \\
\text { Posttreatment: } \\
\text { Pretreatment: AT grade; } \\
\text { Mallampati; } \\
\text { Total sleep time; } \\
\text { AHI, ODI }\end{array}$ & $\begin{array}{l}\text { Beneficial effects } \\
\text { (reduction of AHI and } \\
\text { ODI) in } 71 \% \text { of children } \\
\text { treated with } \\
\text { montelukast. No } \\
\text { changes in those treated } \\
\text { with placebo. }\end{array}$ \\
\hline $\begin{array}{l}\text { Brouillette } \\
\text { R.T. et al. } \\
\text { [54] }\end{array}$ & 2001 & $\begin{array}{l}\text { Triple-blind } \\
\text { randomized } \\
\text { placebo-controlled } \\
\text { trial }\end{array}$ & 25 & $1-10$ & $\begin{array}{c}\text { Age and Sex; } \\
\text { Pretreatment: } \\
\text { AHI, ODI; } \\
\text { Total sleep time; } \\
\text { AT grade; } \\
\text { AR symptoms } \\
\text { Posttreatment: AHI, ODI; } \\
\text { Total sleep time; } \\
\text { AT grade; } \\
\text { AR symptoms }\end{array}$ & $\begin{array}{c}\text { Decrease in AHI/ODI } \\
\text { values in } 12 / 13 \text { of } \\
\text { fluticasone group. No } \\
\text { changes in placebo } \\
\text { group }\end{array}$ \\
\hline
\end{tabular}

\subsection{Craniofacial Abnormalities and Genetics}

Craniofacial abnormalities can also be a cause of upper airway obstruction syndrome. Alterations of the size, position, and geometry of the mandible and of the tongue can lead to the thickening of the retro-palatal region which, as already mentioned above, is the most frequent site of obstruction in pediatric patients. [55,56].

The exact role of genetics in the pathogenesis of pediatric OSAS is still a matter of debate. What is known is that some clinical syndromes such as Down, Prader-Willi and Beckwith-Wiedemann are strongly associated with OSAS. Studies focus mostly on gene polymorphisms, for example, the ApoE4 allele, TNFa 308G gene polymorphism, NADPH polymorphism [57-60].

Zaffanello M. et al. [61] reported other genetic syndromes that could be cause of OSAS: Achondroplasia [62-65], Ehlers-Danlos Syndrome [66,67], Pierre Robin sequence/complex [68], Ellis-van Creveld Syndrome [69], sickle cell disease [70] and Noonan Syndrome [71]. Any congenital or acquired conditions that involve the respiratory control center may potentially lead to the development of OSAS. Myelomeningocele, Arnold Chiari malformation, and brain injuries from trauma, tumors, surgery can be other causes of pediatric OSAS [72,73]. In such patients, surgical treatment often represents the only option possible. Maxillo-mandibular advancement (MMA) is one of the most 
common type of surgical procedures performed in these cases. It provides an enlargement the nasopharynx, oropharynx, and hypopharynx by advancing the soft palate and tongue and shrinking the lateral pharyngeal walls.

Saxby et al. [74] evaluated maxillomandibular advancement surgery as the gold standard for children affected by syndromic craniofacial abnormalities. The procedure showed an improvement of the Apnea-Hypopnea Index score and OSA grading in most of their 65 patients, although measures of oxygenation revealed no differences.

On the other hand, in the adult population, the indication for mid-face advancement should take into account the complication rate and cosmetic sequelae. For this reason, it is not considered as a first line option in children without facial abnormalities [75].

Orthodontic treatment represents a valid alternative in patients only presenting high-arched or narrow palates, susceptible to OSAS. The use of rapid maxillary expansion, an appliance to widen the palate and flatten the palatal arch, has shown very good polysomnographic outcomes in a recent meta-analysis [76]. Villa et al. [77] proposed oral appliance therapy for children presenting moderate to severe OSAS with malocclusion.

Studies that have analyzed craniofacial abnormalities and genetics as pediatric OSA risk factor have been reported in Table 5 .

Table 5. Studies that have analyzed craniofacial abnormalities and genetics as a pediatric OSA risk factor.

\begin{tabular}{|c|c|c|c|c|c|c|}
\hline Study & Year & Type of Study & $\begin{array}{l}\text { Patients } \\
\text { Number }\end{array}$ & Age & Parameters Evaluated & Conclusions \\
\hline $\begin{array}{l}\text { Follmar A. } \\
\text { et al. [58] }\end{array}$ & 2014 & $\begin{array}{l}\text { Retrospective } \\
\text { cohort study }\end{array}$ & 118 & $\begin{array}{l}1 \text { day-15 } \\
\text { years }\end{array}$ & $\begin{array}{c}\text { RDI; } \\
\text { Laryngomalacia; } \\
\text { macroglossia, } \\
\text { AT hypertrophy; } \\
\text { GERD. } \\
\end{array}$ & $\begin{array}{l}\text { Multifactorial etiology of } \\
\text { RSD in children affected by } \\
\text { Prader-Willi Syndrome }\end{array}$ \\
\hline $\begin{array}{l}\text { Onodera K. } \\
\text { et al. [62] }\end{array}$ & 2005 & $\begin{array}{l}\text { Case-control } \\
\text { study }\end{array}$ & 30 & $\begin{array}{l}3.8 \pm 1.4 \\
(20) 7.9 \pm 3 \\
(10)\end{array}$ & $\begin{array}{l}\text { Questionnaire items: } \\
\text { Snoring; } \\
\text { AHI; } \\
\text { Mouth breathing; } \\
\text { Occlusion; } \\
\text { Height and weight; } \\
\text { Ages of the eruption of } \\
\text { deciduous teeth }\end{array}$ & $\begin{array}{l}\text { Significant presence of RSD } \\
\text { in patients affected by } \\
\text { achondroplasia (AP) }\end{array}$ \\
\hline $\begin{array}{l}\text { Pavone M. } \\
\text { et al. [66] }\end{array}$ & 2015 & $\begin{array}{l}\text { Retrospective } \\
\text { study }\end{array}$ & 88 & $1-14.5$ & $\begin{array}{l}\text { Anthropometric data; } \\
\text { BMI; } \\
\text { MOAHI, RDI, SpO2 }\end{array}$ & $\begin{array}{l}\text { No correlations between } \\
\text { MOAHI and age or BMI, } \\
\text { positive correlations } \\
\text { between MOAHI and Sp02 }\end{array}$ \\
\hline $\begin{array}{l}\text { Guilleminault } \\
\text { C. et al. [67] }\end{array}$ & 2013 & $\begin{array}{l}\text { Retrospective } \\
\text { study }\end{array}$ & $\begin{array}{c}34 \\
\text { patients }\end{array}$ & 26.55 & $\begin{array}{l}\text { Clinical evaluation; } \\
\text { Rhinomanometry; } \\
\text { AHI, RDI, Sa02 }\end{array}$ & $\begin{array}{l}\text { Commonly unrecognized } \\
\text { abnormal breathing and its } \\
\text { correlation with daytime } \\
\text { fatigue and poor sleep in } \\
\text { Ehlers-Danlos patients }\end{array}$ \\
\hline $\begin{array}{c}\text { Kalaskar R } \\
\text { et al. [69] }\end{array}$ & 2012 & $\begin{array}{l}\text { Case report } \\
\text { study }\end{array}$ & 1 & $\begin{array}{l}11 \text { years } \\
\text { old boy }\end{array}$ & $\begin{array}{l}\text { Anatomical finding; } \\
\text { orthodontic } \\
\text { conformation }\end{array}$ & $\begin{array}{l}\text { Association between } \\
\text { Ellis-van Creveld } \\
\text { syndrome and OSA }\end{array}$ \\
\hline $\begin{array}{l}\text { Cardiel Rios } \\
\text { S.A. et al. } \\
\text { [71] }\end{array}$ & 2016 & $\begin{array}{l}\text { Case report } \\
\text { study }\end{array}$ & 1 & $\begin{array}{l}10 \text { years } \\
\text { old boy }\end{array}$ & $\begin{array}{l}\text { Anatomical finding; } \\
\text { orthodontic } \\
\text { conformation }\end{array}$ & $\begin{array}{l}\text { Association between } \\
\text { Noonan syndrome, } \\
\text { malocclusion and OSA }\end{array}$ \\
\hline $\begin{array}{l}\text { Saxby C. } \\
\text { et al. [74] }\end{array}$ & 2018 & $\begin{array}{l}\text { Retrospective } \\
\text { study }\end{array}$ & 65 & $\begin{array}{c}\text { Not } \\
\text { specified }\end{array}$ & $\begin{array}{l}\text { Patients demographics; } \\
\text { Type of midface } \\
\text { advancement; } \\
\text { Preoperative: AHI, RDI, } \\
\text { SaO2; } \\
\text { Postoperative: AHI, } \\
\text { RDI, SaO2; } \\
\text { Blood pressure; }\end{array}$ & $\begin{array}{l}\text { Positive outcomes after } \\
\text { midface advancement in } \\
\text { patients with } \\
\text { craniosynostosis }\end{array}$ \\
\hline
\end{tabular}


Table 5. Cont.

\begin{tabular}{ccccccc}
\hline Study & Year & Type of Study & $\begin{array}{c}\text { Patients } \\
\text { Number }\end{array}$ & Age & Parameters Evaluated & Conclusions \\
\hline $\begin{array}{c}\text { Villa M.P. } \\
\text { et al. [77] }\end{array}$ & 2002 & $\begin{array}{c}\text { Randomized } \\
\text { controlled } \\
\text { study }\end{array}$ & 32 & $4-10$ & $\begin{array}{c}\text { Brouillette } \\
\text { questionnaire; } \\
\text { physical examinations: } \\
\text { AHI, RDI, SaO2 }\end{array}$ & $\begin{array}{c}\text { Improved respiratory } \\
\text { symptoms in patients who } \\
\text { underwent oral appliance } \\
\text { treatments }\end{array}$ \\
\hline
\end{tabular}

\subsection{Inflammatory Factors and Biomarkers}

It is believed that inflammation and OSAS are strongly related. In fact, systemic inflammatory markers level such as NF-kB, C-reactive protein (CRP), TNF-a, IL-6, IL-8 IL-1a, IL-1b, and IFN-g are upregulated in subjects with OSAS. On the other hand, the concomitant reduction of anti-inflammatory factor IL-10 suggests a tilted proinflammatory state in OSAS [78-80].

Several studies have highlighted the role of oxidative stress in the genesis of endothelial damage in both adult and pediatric OSAS patients [81,82]. Intermittent hypoxemia leads to anoxia and re-oxygenation, which triggers the production of oxygen radicals and consequently local and systemic inflammation.

Many studies have suggested the involvement of the NF- $\mathrm{kB}$-related inflammatory pathway in the pathogenesis of OSAS. The upregulation of NF- $\mathrm{KB}$ increases the expression of pro-inflammatory mediators and cytokines (TNF- $\alpha$, IL-6, and CRP), resulting in blood vessel endothelial damage and systemic inflammation. It is widely accepted that a correlation exists between systemic inflammation and the progression of atherosclerosis and coronary artery disease in adults.

Although in adults the association between inflammation and OSA is well known, in children it is still under debate. In children, inflammatory markers (local and systemic) and proinflammatory cytokines are upregulated, which further advances lymphoid tissue proliferation. Many studies are being conducted on the use of biomarkers for the diagnosis of OSAS, based on the high levels of pro-inflammatory factors.

Biomarkers are non-invasive and simple tests to integrate diagnosis. Kallikrein-1, orosomucoid-1, uromodulin and urocotin-3 are those most frequently used. In fact, their relevance lies on the diagnostic precision in finding children affected by OSAS [83,84]. Other biomarkers less used are: Serum alpha amylase level, lipocalin-type prostaglandin D synthase, cysteinyl leukotrienes, and urinary 8-isoprostane [85-89]. Although the results seem promising, unfortunately these tests have shown an unreliable specificity and sensitivity. In fact, chronic inflammation can be typical of patients affected by OSAS (both adults and children) or may develop later on. Therefore, biomarkers cannot be used as predictors. For this reason, they should be considered by physicians only as an integration of the data coming from clinical evaluation and PSG.

Studies that have analyzed inflammatory factors and biomarkers as pediatric OSAS risk factor have been reported in Table 6 . 
Table 6. Studies that have analyzed inflammatory factors and biomarkers as pediatric OSAS risk factors.

\begin{tabular}{|c|c|c|c|c|c|c|}
\hline Study & Year & Type of Study & $\begin{array}{l}\text { Patients } \\
n^{\circ}\end{array}$ & Age & Parameters Evaluated & Conclusions \\
\hline $\begin{array}{l}\text { Gozal D. } \\
\text { et al. [59] }\end{array}$ & 2007 & $\begin{array}{l}\text { Prospective } \\
\text { study }\end{array}$ & 355 & $5-7$ & $\begin{array}{l}\text { AHI, RDI, SaO2; } \\
\text { Neurocognitive tests; } \\
\text { Blood draw. }\end{array}$ & $\begin{array}{l}\text { Positive correlation } \\
\text { between APOE epsilon4 } \\
\text { allele and OSA and }\end{array}$ \\
\hline $\begin{array}{l}\text { Khalyfa A. } \\
\text { et al. [60] }\end{array}$ & 2011 & $\begin{array}{l}\text { Case-control } \\
\text { study }\end{array}$ & 140 & $<6$ & $\begin{array}{c}\text { ESS questionnaire; } \\
\text { AHI, RDI, SaO2M; } \\
\text { Serum TNF- } \alpha\end{array}$ & $\begin{array}{c}\text { neurocognitive deficits } \\
\text { Positive correlation } \\
\text { between high TNF- } \alpha \text { levels } \\
\text { and OSAS }\end{array}$ \\
\hline $\begin{array}{l}\text { Tam C.S. } \\
\text { et al. [79] }\end{array}$ & 2006 & $\begin{array}{l}\text { Case-control } \\
\text { study }\end{array}$ & 113 & $7.3 \pm 3.7$ & $\begin{array}{l}\text { C-reactive protein; } \\
\text { Cytokines: IL-1beta, } \\
\text { IL-2, IL-4, IL-6, IL-8, } \\
\text { IL-10, IL-12, GM-CSF, } \\
\text { IFN-gamma and } \\
\text { TNF-alpha. }\end{array}$ & $\begin{array}{l}\text { Significantly elevated } \\
\text { IFN-gamma levels and } \\
\text { elevated IL-8 levels }\end{array}$ \\
\hline $\begin{array}{l}\text { Gozal et al. } \\
\text { [80] }\end{array}$ & 2008 & $\begin{array}{l}\text { Case-control } \\
\text { study }\end{array}$ & 40 & $6.5 \pm 0.7$ & $\begin{array}{l}\text { Age and sex; } \\
\text { Ethnicity; } \\
\text { BMI: } \\
\text { AHI, RDI; } \\
\text { IL-6, IL-10. }\end{array}$ & $\begin{array}{l}\text { Higher levels of IL- } 6 \text { and } \\
\text { IL-10 }\end{array}$ \\
\hline $\begin{array}{l}\text { Park C.S. } \\
\text { et al. [85] }\end{array}$ & 2014 & $\begin{array}{l}\text { Case-control } \\
\text { study }\end{array}$ & 67 & $6(3-16)$ & $\begin{array}{c}\text { Age and sex; } \\
\text { BMI; } \\
\text { AHI, RDI; } \\
\text { OSA-18 questionnaire; } \\
\text { Alpha amilase levels. }\end{array}$ & $\begin{array}{l}\text { High level of serum alpha } \\
\text { amilase in severe OSAS } \\
\text { children compared to } \\
\text { moderate and mild ones } \\
\text { and to the control group }\end{array}$ \\
\hline $\begin{array}{l}\text { Gozal D. } \\
\text { et al. [86] }\end{array}$ & 2009 & $\begin{array}{l}\text { Case-control } \\
\text { study }\end{array}$ & 60 & $6.6 \pm 0.7$ & $\begin{array}{c}\text { Clinical questionnaires; } \\
\text { Height and weight; } \\
\text { BMI; } \\
\text { AHI; RDI, SaO2; } \\
\text { Urine collection }\end{array}$ & $\begin{array}{l}\text { Consistent alterations in } \\
\text { urinary concentrations of } \\
\text { specific protein clusters in } \\
\text { OSA patients }\end{array}$ \\
\hline
\end{tabular}

\section{Clinical Presentation}

The clinical presentation of a child with OSAS is quite suggestive and can be divided into physical findings and symptoms. At general examination, these patients present obesity, long face syndrome, craniofacial alterations, and elevated systemic blood pressure. Moreover, the ENT physical examination may frequently show adeno-tonsillar hypertrophy, inflammation of the nasal mucosa, deviation of the nasal septum, hypertrophy of the inferior turbinates, ogival palate, or macroglossia. [90,91].

The symptoms are classically divided into nocturnal and diurnal. Among the latter, the most frequent are daytime sleepiness, recurrent headache, nasal speech, hyperactivity, inattention, depression, mood instability, irritability, and aggressiveness [92,93].

Nocturnal symptoms include snoring, witnessed apnea, oral breathing, paradoxical thoracic movements, nightmares, sleepwalking, and nocturnal enuresis [94]. The well-known long-term complications in the adult population should also be mentioned, because they may also occur in the OSA pediatric population. In fact, several studies have shown an increased risk of cardiovascular and pulmonary complications, such as pulmonary hypertension, or pulmonale and right heart failure. Indeed, high levels of CRP, brain natriuretic peptide, adhesion molecules, myeloid-related protein 8/14, fatty acid-binding protein, and other factors resulting from vascular injury and endothelial activation have all been demonstrated in children with OSAS [95,96].

Moreover, children affected by severe OSAS may develop an early metabolic syndrome. This critical condition is characterized by a cluster of pathologies: Obesity, insulin resistance, systemic hypertension, and dyslipidemia. Although the association is still not clear, several studies have highlighted the link between sleep fragmentation and intermittent hypoxia in obese children and down-regulated insulin sensitivity [97-101]. 


\section{Diagnosis}

The diagnosis of pediatric OSAS is a process composed of several steps. In children the clinical presentation is more nuanced and therefore simple clinical evaluation is often misleading. The clinical history of patients with suspected OSAS is reconstructed by administering specific questionnaires to their parents. The role of the questionnaires and their effectiveness in the diagnostic process are currently under study. In particular, of all those developed, six are the most interesting and most frequently used in clinical practice.

The Pediatric Sleep Questionnaire (PSQ) is the most widely used survey consisting of 22 close-ended questions.

The current guidelines of the European Respiratory Society Task Force define PSQ as a good test for identifying children affected by OSAS with an apnea-hypopnea index (AHI) $>5$ [102].

Other less frequently used questionnaires are: Sleep clinical record (SCR) [103], OSA-18 [104], the Broullette score (BS), and I'M SLEEPY [105].

The latest and newest one is the Sleeping Sleepless Sleepy Disturbed Rest questionnaire (SSSDR). Presented in Rome in 2018, it is not included in the latest guidelines but seems to be very promising [106].

The work of Burghard et al. [107] has summed up these questionnaires. Although very useful, they still need more studies in order to be improved or to further diagnostic steps. Following the assessment of the medical history and questionnaires, the general and ENT examination is of primary importance. The general physical examination evaluates the following parameters: Height and weight growth, neuro-behavioral factors, cardiological and pneumological conditions, and eventual co-morbidities. Therefore, the collaboration between several specialists appears to be fundamental. The ENT physical examination includes an accurate assessment of the upper airway. Adenoid hypertrophy is assessed by nasal endoscopy. There are conflicting opinions on what the role of isolated adenoid hypertrophy in the genesis of OSAS may be. In fact, many studies show that adenoid hypertrophy is not sufficient to determine OSAS, but it can worsen its severity in children with other risk factors [108]. As already mentioned, tonsillar hypertrophy is one of the most frequent causes of OSAS in otherwise healthy children and there is also a correlation between tonsillar grade and OSAS severity [109].

However, not all children with marked tonsillar hypertrophy are affected by OSAS. Thus, there is an individual variability regarding the upper airway muscle tone. Particularly in obese children and in those suffering from neuromuscular diseases, tonsillar hypertrophy does not play a significant role [110].

The presence of dento-facial anomalies also belongs to the typical presentation of an OSA child. For this reason, the ENT specialist should also involve the orthodontist who, by assessing the extra and intra-oral morphological characteristics, can select patients suitable for conservative treatment. However, recent studies have shown that the adenotonsillectomy is capable of restoring correct maxillo-mandibular morphology, thus supporting the thesis that dento-facial skeletal anomalies are more a consequence of OSA than the cause [111].

Nocturnal oximetry is the most widely used screening technique for children with a strong clinical suspicion of pediatric OSAS. In fact, it has a low cost and is easy to carry out and interpret. Although its positivity permits the diagnosis of OSAS, its negativity does not exclude the pathology. According to Kirk et al. [112], the sensitivity and specificity of oximetry for the identification of moderate OSAS (AHI $>5 / \mathrm{h}$ ), compared to the laboratory PSG test, were $67 \%$ and $60 \%$, respectively. These authors also noticed that the oximetry algorhythm tended to overestimate the ODI at low levels and underestimate at high levels. For that reason, oximetry alone was not adequate for the diagnosis of OSAS.

Ambulatory polysomnography is the monitoring of cardiorespiratory features during sleep performed at the patient's home. Despite the high sensitivity and specificity of the examination carried out on adult patients, its effectiveness in children is strongly related to their age. In fact, although there are several studies which validate its efficacy in school-aged children, there are a few discrepancies in the data regarding younger children [113]. Zucconi et al. [114] proposed a home portable system comprising measurements of airflow, snoring, chest and abdominal wall movements, 
electrocardiography (ECG), position, and oximetry. They used it in the sleep laboratory for the study. A small sample of 12 children, 3 to 6 years of age, underwent routine PSG and in-laboratory portable testing on consecutive nights using the portable system. The outcome showed a good sensitivity for detecting a respiratory distress index, but a poor specificity. Nocturnal laboratory polysomnography is considered the gold standard in children in whom there is a high suspicion of OSAS. It is performed monitoring modifications in the electroencephalogram during sleep as well as cardiorespiratory function, airflow, and nocturnal oximetry. It is indicated for quantifying the severity of the disease, for preoperative evaluation, for predicting post-operative complications and the persistence of sleep breathing disorders after treatment. An important aspect is that the compliance to this exam is different in children and in adults. In fact, there is an anxious component in adults that does not allow adequate sleep. The same does not occur in children. This is well explained in several studies which have evaluated the so-called night-to-night variability, and ended up with the result that, in children, one night PSG is adequate. [115-118].

There is another test used in children: Nap PSG. It records sleeping and breathing in laboratory conditions during daytime. It is a simple and reliable test with a high sensibility and specificity [119].

Drug-induced sleep endoscopy (DISE) is mainly used in the pediatric population for the correct approach to children with residual OSAS after surgery. The main goal is to analyze the type of obstruction at the anatomical site of potential collapse [120].

The anesthetic protocol represents a debated point. Inhalation therapy with halothane or sevoflurane was used at the beginning, but several alterations to the pharyngeal muscle tone have led to it being progressively substituted by intravenous drugs, such as propofol, ketamine with glycopyrrolate, remifentanil, and midazolam [120].

Chen et al. [121] evaluated the role of DISE in the diagnosis and consequent aimed treatment in children with small tonsils. Their conclusion was that DISE is also required to evaluate the necessity of combined adenotonsillectomy in patients with a finding of small tonsils at clinical examinations. They focused on the differences between awake endoscopy and DISE. The main one is the possible underestimation of collapse in wakefulness. Moreover, the oropharynx obstruction was better defined in DISE than in awake endoscopy.

In conclusion, although DISE has a well-defined codification in adults, the same cannot be said for children. This could be considered a paradox considering that the first study published in the literature regarding sleep endoscopy was the one by Croft in 1990 in a pediatric population [122].

\section{Conclusions}

Obstructive sleep apnea in children is a condition with a multi-factorial etiology. The study of each single risk factor and of the associated comorbidities as well as the continuous monitoring of the patients are therefore of fundamental importance in order to be able to plan and eventually modify the therapeutic process correctly.

Author Contributions: G.G.: Substantial contributions to the conception and design of the work; acquisition, analysis, and interpretation of data; revising the work; final approval of the version to be published; agreement to be accountable for all aspects of the work. G.I.: Substantial contributions to the conception and design of the work; acquisition, analysis, and interpretation of data; revising the work; final approval of the version to be published; agreement to be accountable for all aspects of the work. C.V.: Substantial contributions to the conception and design of the work; acquisition, analysis, and interpretation of data; revising the work; final approval of the version to be published; agreement to be accountable for all aspects of the work. A.P.: Substantial contributions to the conception and design of the work; acquisition, analysis, and interpretation of data; revising the work; final approval of the version to be published; agreement to be accountable for all aspects of the work. A.G.: Substantial contributions to the conception and design of the work; acquisition, analysis, and interpretation of data; revising the work; final approval of the version to be published; agreement to be accountable for all aspects of the work. M.D.V.: Substantial contributions to the conception and design of the work; acquisition, analysis, and interpretation of data; revising the work; final approval of the version to be published; agreement to be accountable for all aspects of the work. I.C.V.: Substantial contributions to the conception and design of the work; acquisition, analysis, and interpretation of data; revising the work; final approval of the version to be published; agreement to be accountable for all aspects of the work. G.M. (Giuseppe Meccariello): Substantial 
contributions to the conception and design of the work; acquisition, analysis, and interpretation $\mathrm{n}$ of data; revising the work; final approval of the version to be published; agreement to be accountable for all aspects of the work. G.C.: Substantial contributions to the conception and design of the work; acquisition, analysis, and interpretation of data; revising the work; final approval of the version to be published; agreement to be accountable for all aspects of the work. A.D.V.: Substantial contributions to the conception and design of the work; acquisition, analysis, and interpretation of data; revising the work; final approval of the version to be published; agreement to be accountable for all aspects of the work. R.G.: Substantial contributions to the conception and design of the work; acquisition, analysis, and interpretation of data; revising the work; final approval of the version to be published; agreement to be accountable for all aspects of the work. C.B.: Substantial contributions to the conception and design of the work; acquisition, analysis, and interpretation of data; revising the work; final approval of the version to be published; agreement to be accountable for all aspects of the work. E.F.: Substantial contributions to the conception and design of the work; acquisition, analysis, and interpretation of data; revising the work; final approval of the version to be published; agreement to be accountable for all aspects of the work. A.P. (Annalisa Pace): Substantial contributions to the conception and design of the work; acquisition, analysis, and interpretation of data; revising the work; final approval of the version to be published; agreement to be accountable for all aspects of the work. A.C.: Substantial contributions to the conception and design of the work; acquisition, analysis, and interpretation of data; revising the work; final approval of the version to be published; agreement to be accountable for all aspects of the work. S.P.: Substantial contributions to the conception and design of the work; acquisition, analysis, and interpretation of data; revising the work; final approval of the version to be published; agreement to be accountable for all aspects of the work. G.M.: Substantial contributions to the conception and design of the work; acquisition, analysis, and interpretation of data; revising the work; final approval of the version to be published; agreement to be accountable for all aspects of the work. Manuscript have not been published previously in print or electronic format and are not under consideration by another publication or electronic medium.

Funding: This research received no external funding.

Conflicts of Interest: The authors declare no conflict of interest.

\section{Abbreviations}

$\begin{array}{ll}\text { AASM } & \text { American Association Sleep Medicine } \\ \text { AHI } & \text { Apnea-Hypopnea index } \\ \text { AT } & \text { Adenotonsillectomy } \\ \text { AR } & \text { Allergic Rhinitis } \\ \text { BMI } & \text { Body Mass Index } \\ \text { CPAP } & \text { Continuous Positive Airway Pressure } \\ \text { CRP } & \text { Reactive C- Protein } \\ \text { DISE } & \text { Drug Induced Sleep Endoscopy } \\ \text { ERS } & \text { European Respiratory Society } \\ \text { ESS } & \text { Epworth Sleepiness Scale } \\ \text { ICSD-3 } & \text { International Classification of Sleep Disorders } \\ \text { ODI } & \text { Oxygen Desaturation Index } \\ \text { OSA } & \text { Obstructive sleep apnea } \\ \text { OSAS } & \text { Obstructive sleep apnea syndrome } \\ \text { PSG } & \text { Polysomnography } \\ \text { PSQ } & \text { Pediatric Sleep Questionnaire } \\ \text { RDI } & \text { Respiratory Disease Index } \\ \text { REM } & \text { Rapid Eye Movement } \\ \text { RERAs } & \text { Respiratory Effort Related Arousal } \\ \text { RSD } & \text { Respiratory Sleep Disorder } \\ \text { SSSDR } & \text { Sleeping Sleepless Sleepy Disturbed Rest questionnaire }\end{array}$

\section{References}

1. Schechter, M.S. Technical report: Diagnosis and management of childhood obstructive sleep apnea syndrome. Pediatrics 2002, 109, 69. [CrossRef] [PubMed]

2. Gozal, D.; Kheirandish-Gozal, L. Obesity and excessive daytime sleepiness in prepubertal children with obstructive sleep apnea. Pediatrics 2009, 123, 13-18. [CrossRef] [PubMed]

3. American Academy of Sleep Medicine. International Classification of Sleep Disorders, 3rd ed.; American Academy of Sleep Medicine: Darien, IL, USA, 2014. 
4. Berry, R.B.; Budhiraja, R.; Gottlieb, D.J.; Gozal, D.; Iber, C.; Kapur, V.K.; Marcus, C.L.; Mehra, R.; Parthasarathy, S.; Quan, S.F.; et al. The AASM Manual for the Scoring of Sleep and Associated Events: Rules, Terminology and Technical Specifications. Version 2.3; American Academy of Sleep Medicine: Darien, IL, USA, 2016.

5. Ruehland, W.R.; Rochford, P.D.; O’Donoghue, F.J.; Pierce, R.J.; Singh, P.; Thornton, A.T. The new AASM criteria for scoring hypopneas: Impact on the apnea hypopnea index. Sleep 2009, 32, 150-157. [CrossRef] [PubMed]

6. Redline, S.; Kapur, V.K.; Sanders, M.H.; Quan, S.F.; Gottlieb, D.J.; Rapoport, D.M.; Bonekat, W.H.; Smith, P.L.; Kiley, J.P.; Iber, C. Effects of varying approaches for identifying respiratory disturbances on sleep apnea assessment. Am. J. Respir. Crit. Care. Med. 2000, 161, 369-374. [CrossRef] [PubMed]

7. Duce, B.; Milosavljevic, J.; Hukins, C. The 2012 AASM respiratory event criteria increase the incidence of hypopneas in an adult sleep center population. J. Clin. Sleep Med. 2015, 11, 1425-1431. [CrossRef] [PubMed]

8. Vicini, C.; De Vito, A.; Iannella, G.; Gobbi, R.; Corso, R.M.; Montevecchi, F.; Polimeni, A.; De Vincentiis, M.; Meccariello, G.; D'agostino, G.; et al. The aging effect on upper airways collapse of patients with obstructive sleep apnea syndrome. Eur. Arch. Otorhinolaryngol. 2018, 275, 2983-2990. [CrossRef] [PubMed]

9. Marcus, C.L.; Brooks, L.J.; Draper, K.A.; Gozal, D.; Halbower, A.C.; Jones, J.; Schechter, M.S.; Ward, S.D.; Sheldon, S.H.; Shiffman, R.N.; et al. Diagnosis and Management of Childhood Obstructive Sleep Apnea Syndrome. Pediatrics 2012, 130, 576-584. [CrossRef] [PubMed]

10. Katz, E.S.; D'Ambrosio, C.M. Pathophysiology of Pediatric Obstructive Sleep Apnea. Proc. Am. Thorac. Soc. 2008, 5, 253-262. [CrossRef]

11. Kaditis, A.G.; Alonso Alvarez, M.L.; Boudewyns, A.; Alexopoulos, E.I.; Ersu, R.; Joosten, K.; Larramona, H.; Miano, S.; Narang, I.; Trang, H.; et al. Obstructive sleep disordered breathing in 2- to 18-year-old children: Diagnosis and management. Eur. Respir. J. 2016, 47, 69-94. [CrossRef]

12. Carter, K.A.; Hathaway, N.E.; Lettieri, C.F. Common sleep disorders in children. Am. Fam. Physician 2014, 89, 368-377.

13. Gozal, D.; Kheirandish-Gozal, L. New approaches to the diagnosis of sleep-disordered breathing in children. Sleep Med. 2010, 11, 708-713. [CrossRef] [PubMed]

14. Tan, H.L.; Gozal, D.; Kheirandish-Gozal, L. Obstructive sleep apnea in children: A critical update. Nat. Sci. Sleep 2013, 5, 109-123. [PubMed]

15. Lumeng, J.C.; Chervin, R.D. Epidemiology of pediatric obstructive sleep apnea. Proc. Am. Thorac. Soc. 2008, 5, 242-252. [CrossRef] [PubMed]

16. Li, Z.; Celestin, J.; Lockey, R.F. Pediatric Sleep Apnea Syndrome: An Update. J. Allergy Clin. Immunol. Pract. 2016, 4, 852-861. [CrossRef] [PubMed]

17. Van de Graaff, W.B. Thoracic traction on the trachea: Mechanisms and magnitude. J. Appl. Physiol. 1991, 70, 1328-1336. [CrossRef] [PubMed]

18. Arens, R.; Sin, S.; Nandalike, K.; Rieder, J.; Khan, U.I.; Freeman, K.; Wylie-Rosett, J.; Lipton, M.L.; Wootton, D.M.; McDonough, J.M.; et al. Upper airway structure and body fat composition in obese children with obstructive sleep apnea syndrome. Am. J. Respir. Crit. Care Med. 2011, 183, 782-787. [CrossRef] [PubMed]

19. Hannon, T.S.; Rofey, D.L.; Ryan, C.M.; Clapper, D.A.; Chakravorty, S.; Arslanian, S.A. Relationships among obstructive sleep apnea, anthropometric measures, and neurocognitive functioning in adolescents with severe obesity. J. Pediatr. 2012, 160, 732-735. [CrossRef] [PubMed]

20. NCD Risk Factor Collaboration (NCD-RisC). Worldwide trends in body-mass index, underweight, overweight, and obesity from 1975 to 2016: A pooled analysis of 2416 population-based measurement studies in 128.9 million children, adolescents, and adults. Lancet 2017, 390, 2627-2642. [CrossRef]

21. Su, M.S.; Zhang, H.L.; Cai, X.H.; Lin, Y.; Liu, P.N.; Zhang, Y.B.; Hu, W.Z.; Li, C.C.; Xiao, Y.F. Obesity in children with different risk factors for obstructive sleep apnea: A community-based study. Eur. J. Pediatr. 2016, 175, 211-220. [CrossRef]

22. O'Brien, I.M.; Sitha, S.; Baur, L.A.; Waters, K.A. Obesity increases the risk for persisting obstructive sleep apnea after treatment in children. Int. J. Pediatr. Otorhinolaryngol. 2006, 70, 1555-1560. [CrossRef]

23. Mitchell, R.B.; Kelly, J. Outcome of adenotonsillectomy for obstructive sleep apnea in obese and normal-weight children. Otolaryngol. Head Neck Surg. 2007, 137, 43-48. [CrossRef] [PubMed] 
24. Marcus, C.L.; Rosen, G.; Ward, S.L.; Halbower, A.C.; Sterni, L.; Lutz, J.; Stading, P.J.; Bolduc, D.; Gordon, N. Adherence to and effectiveness of positive airway pressure therapy in children with obstructive sleep apnea. Pediatrics 2006, 117, e442-e451. [CrossRef] [PubMed]

25. Marcus, C.L.; Ward, S.L.; Mallory, G.B.; Rosen, C.L.; Beckerman, R.C.; Weese-Mayer, D.E.; Brouillette, R.T.; Trang, H.T.; Brooks, L.J. Use of nasal continuous positive airway pressure as treatment of childhood obstructive sleep apnea. J. Pediatr. 1995, 127, 88-94. [CrossRef]

26. Xu, Z.; Jiaqing, A.; Yuchuan, L.; Shen, K. A case-control study of obstructive sleep apnea-hypopnea syndrome in obese and nonobese Chinese children. Chest 2008, 133, 684-689. [CrossRef] [PubMed]

27. Verhulst, S.L.; Franckx, H.; Van Gaal, L.; De Backer, W.; Desager, K. The effect of weight loss on sleep-disordered breathing in obese teenagers. Obesity 2009, 17, 1178-1183. [PubMed]

28. Siegfried, W.; Siegfried, A.; Rabenbauer, M.; Hebebrand, J. Snoring and sleep apnea in obese adolescents: Effect of long-term weight loss-rehabilitation. Sleep Breath. 1999, 3, 83-88. [CrossRef]

29. Van Hoorenbeeck, K.; Franckx, H.; Debode, P.; Aerts, P.; Wouters, K.; Ramet, J.; Van Gaal, L.F.; Desager, K.N.; De Backer, W.A.; Verhulst, S.L. Weight loss and sleep-disordered breathing in childhood obesity: Effects on inflammation and uric acid. Obesity 2012, 20, 172-177. [CrossRef]

30. Andersen, I.G.; Holmb, J.C.; Homøea, P. Impact of weight-loss management on children and adolescents with obesity and obstructive sleep apnea. Int. J. Pediatr. Otorhinolaryngol. 2019, 123, 57-62. [CrossRef]

31. Marcus, C.L. Pathophysiology of childhood obstructive sleep apnea: Current concepts. Respir. Physiol. 2000, 119, 143-154. [CrossRef]

32. Jeans, W.D.; Fernando, D.C.; Maw, A.R.; Leighton, B.C. A longitudinal study of the growth of the nasopharynx and its contents in normal children. Br. J. Radiol. 1981, 54, 117-121. [CrossRef]

33. Kurnatowski, P.; Putynski, L.; Łapienis, M.; Kowalska, B. Physical and emotional disturbances in children with adenotonsillar hypertrophy. J. Laryngol. Otol. 2008, 122, 931-935. [CrossRef] [PubMed]

34. Brietzke, S.E.; Gallagher, D. The effectiveness of tonsillectomy and adenoidectomy in the treatment of pediatric obstructive sleep apnea/hypopnea syndrome: A meta-analysis. Otolaryngol. Head Neck Surg. 2006, 134, 979-984. [CrossRef] [PubMed]

35. Tang, A.L.; Cohen, A.P.; Benke, J.R.; Stierer, K.D.; Stanley, J.; Ishman, S.L. Obstructive Sleep Apnea Resolution in Hypopnea- versus Apnea-Predominant Children after Adenotonsillectomy. Otolaryngol. Head Neck Surg. 2016, 155, 670-675. [CrossRef] [PubMed]

36. El-Kersh, K.; Cavallazzi, R.; Senthilvel, E. Outcomes of adenotonsillectomy in severe pediatric obstructive sleep apnea. Ear Nose Throat J. 2017, 96, E6-E9. [PubMed]

37. Senchak, A.J.; McKinlay, A.J.; Acevedo, J.; Swain, B.; Tiu, M.C.; Chen, B.S.; Robitschek, J.; Ruhl, D.S.; Williams, L.L.; Camacho, M.; et al. The effect of tonsillectomy alone in adult obstructive sleep apnea. Otolaryngol. Head Neck Surg. 2015, 152, 969-973. [CrossRef]

38. Kang, K.T.; Koltai, P.J.; Lee, C.H.; Lin, M.T.; Hsu, W.C. Lingual tonsillectomy for treatment of pediatric obstructive sleep apnea: A meta-analysis. JAMA Otolaryngol. Head Neck Surg. 2017, 143, 561-568. [CrossRef] [PubMed]

39. Iannella, G.; Magliulo, G.; Montevecchi, F.; De Vito, A.; Polimeni, A.; De Vincentiis, M.; Meccariello, G.; D’Agostino, G.; Gobbi, R.; Cammaroto, G.; et al. Lingual tonsil lymphatic tissue regrowth in patients undergoing transoral robotic surgery. Laryngoscope 2018. [CrossRef] [PubMed]

40. Pynnonen, M.; Brinkmeier, J.V.; Thorne, M.C.; Chong, L.Y.; Burton, M.J. Coblation versus other surgical techniques for tonsillectomy. Cochrane Database Syst. Rev. 2017, 8, CD004619. [CrossRef]

41. Lee, C.F.; Hsu, W.C.; Lee, C.H.; Lin, M.T.; Kang, K.T. Treatment outcomes of supraglottoplasty for pediatric obstructive sleep apnea: A meta-analysis. Int. J. Pediatr. Otorhinolaryngol. 2016, 87, 18-27. [CrossRef]

42. Kimple, A.; Ishman, S. Allergy and sleep-disordered breathing. Curr. Opin. Otolaryngol. Head Neck Surg. 2013, 21, 277-281. [CrossRef]

43. Miljeteig, H.; Hoffstein, V.; Cole, P. The effect of unilateral and bilateral nasal obstruction on snoring and sleep apnoea. Laryngoscope 1992, 102, 1150-1152. [CrossRef] [PubMed]

44. Young, T.; Finn, L.; Kim, H. Nasal obstruction as a risk factor for sleep-disordered breathing. J. Allergy Clin. Immunol. 1997, 99, S757-S762. [CrossRef]

45. Magliulo, G.; de Vincentiis, M.; Iannella, G.; Ciofalo, A.; Pasquariello, B.; Manno, A.; Angeletti, D.; Polimeni, A. Olfactory evaluation in obstructive sleep apnoea patients. Acta Otorhinolaryngol. Ital. 2018, 38, 338-345. [PubMed] 
46. Magliulo, G.; Iannella, G.; Ciofalo, A.; Polimeni, A.; de Vincentiis, M.; Pasquariello, B.; Montevecchi, F.; Vicini, C. Nasal pathologies in patients with obstructive sleep apnoea. Acta Otorhinolaryngol. Ital. 2019. [CrossRef] [PubMed]

47. Lofaso, F.; Coste, A.; d'Ortho, M.P.; Zerah-Lancner, F.; Delclaux, C.; Goldenberg, F.; Harf, A. Nasal obstruction as a risk factor for sleep apnoea syndrome. Eur. Respir. J. 2000, 16, 639-643. [CrossRef] [PubMed]

48. McNicholas, W.T.; Tarlo, S.; Cole, P.; Zamel, N.; Rutherford, R.; Griffin, D.; Phillipson, E.A. Obstructive apneas during sleep in patients with seasonal allergic rhinitis. Am. Rev. Respir. Dis. 1982, 126, 625-628. [PubMed]

49. Liistro, G.; Rombaux, P.; Belge, C.; Dury, M.; Aubert, G.; Rodenstein, D.O. High Mallampati score and nasal obstruction are associated risk factors for obstructive sleep apnoea. Eur. Respir. J. 2003, 21, 248-252. [CrossRef] [PubMed]

50. Di Francesco, R.; Alvarez, J. Allergic rhinitis affects the duration of rapid eye movement sleep in children with sleep-disordered breathing without sleep apnea. Int. Forum Allergy Rhinol. 2016, 6, 465-471. [CrossRef]

51. Cao, Y.; Wu, S.; Zhang, L.; Yang, Y.; Cao, S.; Li, Q. Association of allergic rhinitis with obstructive sleep apnea: A meta-analysis. Medicine 2018, 97, 13783. [CrossRef]

52. Kheirandish-Gozal, L.; Bhattacharjee, R.; Bandla, H.P.R.; Gozal, D. Antinflammatory therapy outcomes for mild osa in children. Chest 2014, 146, 88-95. [CrossRef]

53. Kheirandish-Gozal, L.; Bandla, H.P.; Gozal, D. Montelukast for children with obstructive sleep apnea: Results of a double-blind, randomized, placebocontrolled trial. Ann. Am. Thorac. Soc. 2016, 13, 1736-1741. [CrossRef] [PubMed]

54. Brouillette, R.T.; Manoukian, J.J.; Ducharme, F.M.; Oudjhane, K.; Earle, L.G.; Ladan, S.; Morielli, A. Efficacy of fluticasone nasal spray for pediatric obstructive sleep apnea. J. Pediatr. 2001, 138, 838-844. [CrossRef] [PubMed]

55. Myer, C.M., 3rd; Reed, J.M.; Cotton, R.T.; Willging, J.P.; Shott, S.R. Airway management in Pierre Robin sequence. Otolaryngol. Head Neck Surg. 1998, 118, 630-635. [CrossRef] [PubMed]

56. Scott, A.R.; Tibesar, R.J.; Sidman, J.D. Pierre Robin sequence: Evaluation, management, indications for surgery, and pit-falls. Otolaryngol. Clin. North Am. 2012, 45, 695-710. [CrossRef] [PubMed]

57. Cohen, M.; Hamilton, J.; Narang, I. Clinically important age-related differences in sleep related disordered breathing in infants and children with Prader-Willi Syndrome. PLoS ONE 2014, 9, 101012. [CrossRef] [PubMed]

58. Follmar, A.; Dentino, K.; Abramowicz, S.; Padwa, B.L. Prevalence of sleep disordered breathing in patients with Beckwith-Wiedemann syndrome. J. Craniofac. Surg. 2014, 25, 1814-1817. [CrossRef]

59. Gozal, D.; Capdevila, O.S.; Kheirandish-Gozal, L.; Crabtree, V.M. APOE epsilon 4 allele, cognitive dysfunction, and obstructive sleep apnea in children. Neurology 2007, 69, 243-249. [CrossRef]

60. Khalyfa, A.; Serpero, L.D.; Kheirandish-Gozal, L.; Capdevila, O.S.; Gozal, D. TNFalpha gene polymorphisms and excessive daytime sleepiness in pediatric obstructive sleep apnea. J. Pediatr. 2011, 158, 77-82. [CrossRef]

61. Zaffanello, M.; Antoniazzi, F.; Tenero, L.; Nosetti, L.; Piazza, M.; Piacentini, G. Sleep-disordered breathing in paediatric setting: Existing and upcoming of the genetic disorders. Ann. Transl. Med. 2018, 6, 343. [CrossRef]

62. Onodera, K.; Sakata, H.; Niikuni, N.; Nonaka, T.; Kobayashi, K.; Nakajima, I. Survey of the present status of sleep-disordered breathing in children with achondroplasia Part, I. A questionnaire survey. Int. J. Pediatr. Otorhinolaryngol. 2005, 69, 457-461. [CrossRef]

63. Collins, W.O.; Choi, S.S. Otolaryngologic manifestations of achondroplasia. Arch. Otolaryngol. Head Neck Surg. 2007, 133, 237-244. [CrossRef]

64. Cielo, C.M.; Konstantinopoulou, S.; Hoque, R. OSAS in Specific Pediatric Populations. Curr. Probl. Pediatr. Adolesc. Health Care. 2016, 46, 11-18. [CrossRef] [PubMed]

65. Slaats, M.A.L.J.; Loterman, D.; van Holsbeke, C.; Vos, W.; Van Hoorenbeeck, K.; de Backer, J.; de Backer, W.; Wojciechowski, M.; Boudewyns, A.; Verhulst, S. The Role of Functional Respiratory Imaging in Treatment Selection of Children With Obstructive Sleep Apnea and Down Syndrome. J. Clin. Sleep Med. 2018, 14, 651-659. [CrossRef] [PubMed]

66. Pavone, M.; Caldarelli, V.; Khirani, S.; Colella, M.; Ramirez, A.; Aubertin, G.; Crinò, A.; Brioude, F.; Gastaud, F.; Beydon, N.; et al. Sleep disordered breathing in patients with Prader-Willi syndrome: A multicenter study. Pediatr. Pulmonol. 2015, 50, 1354-1359. [CrossRef] [PubMed] 
67. Guilleminault, C.; Primeau, M.; Chiu, H.Y.; Yuen, K.M.; Leger, D.; Metlaine, A. Sleep-disordered breathing in Ehlers-Danlos syndrome: A genetic model of OSA. Chest 2013, 144, 1503-1511. [CrossRef] [PubMed]

68. Robin, P. Glossoptosis due to atresia and hypotrophy of the mandible. Am. J. Dis. Child. 1934, 48, 541-547. [CrossRef]

69. Kalaskar, R.; Kalaskar, A.R. Oral manifestations of Ellis-van Creveld syndrome. Contemp. Clin. Dent. 2012, 3 , S55-S59. [CrossRef]

70. Strauss, T.; Sin, S.; Marcus, C.L.; Mason, T.B.A.; McDonough, J.M.; Allen, J.L.; Caboot, J.B.; Bowdre, C.Y.; Jawad, A.F.; Smith-Whitley, K.; et al. Upper airway lymphoid tissue size in children with sickle cell disease. Chest 2012, 142, 94-100. [CrossRef]

71. Cardiel Ríos, S.A. Correction of a severe Class II malocclusion in a patient with Noonan syndrome. Am. J. Orthod. Dentofac. Orthop. 2016, 150, 511-520. [CrossRef]

72. Marcus, C.L.; Lutz, J.; Carroll, J.L.; Bamford, O. Arousal and ventilatory responses during sleep in children with obstructive sleep apnea. J. Appl. Physiol. 1998, 84, 1926-1936. [CrossRef]

73. Tauman, R.; Gozal, D. Obstructive sleep apnea syndrome in children. ExpertRev. Respir. Med. 2011, 5, 425-440. [CrossRef] [PubMed]

74. Saxby, C.; Stephenson, K.A.; Steele, K.; Ifeacho, S.; Wyatt, M.E.; Samuels, M. The Effect of Midface Advancement Surgery on Obstructive Sleep Apnoea in Syndromic Craniosynostosis. J. Craniofac. Surg. 2018, 29, 92-95. [CrossRef] [PubMed]

75. Verse, T.; Hörmann, K. The surgical treatment of sleep-related upper airway obstruction. Dtsch. Arztebl. Int. 2011, 108, 216-221. [CrossRef] [PubMed]

76. Camacho, M.; Chang, E.T.; Song, S.A.; Abdullatif, J.; Zaghi, S.; Pirelli, P.; Certal, V.; Guilleminault, C. Rapid maxillary expansion for pediatric obstructive sleep apnea: A systematic review and meta-analysis. Laryngoscope 2017, 127, 1712-1719. [CrossRef] [PubMed]

77. Villa, M.P.; Bernkopf, E.; Pagani, J.; Broia, V.; Montesano, M.; Ronchetti, R. Randomized controlled study of an oral jaw-positioning appliance for the treatment of obstructive sleep apnea in children with malocclusion. Am. J. Respir. Crit. Care. Med. 2002, 165, 123-127. [CrossRef] [PubMed]

78. Gileles-Hillel, A.; Alonso-Álvarez, M.L.; Kheirandish-Gozal, L.; Peris, E.; Cordero-Guevara, J.A.; Terán-Santos,J.; Martinez, M.G.; Jurado-Luque, M.J.; Corral-Peñafiel, J.; Duran-Cantolla, J.; et al. Inflammatory markers and obstructive sleep apnea in obese children: The NANOS study. Mediat. Inflamm. 2014, 2014, 605280. [CrossRef] [PubMed]

79. Tam, C.S.; Wong, M.; McBain, R.; Bailey, S.; Waters, K.A. Inflammatory measures in children with obstructive sleep apnoea. J. Paediatr. Child. Health 2006, 42, 277-282. [CrossRef]

80. Gozal, D.; Serpero, L.D.; Sans Capdevila, O.; Kheirandish-Gozal, L. Systemic inflammation in non-obese children with obstructive sleep apnea. Sleep Med. 2008, 9, 254-259. [CrossRef]

81. Ciccone, M.M.; Scicchitano, P.; Mitacchione, G.; Zito, A.; Gesualdo, M.; Caputo, P.; Damiani, M.F.; Sassara, M.; Favale, S.; Resta, O.; et al. Is there a correlation between OSAS duration/severity and carotid intima-media thickness? Respir. Med. 2012, 106, 740-746. [CrossRef]

82. Lu, D.; Li, N.; Yao, X.; Zhou, L. Potential inflammatory markers in obstructive sleep apnea-hypopnea syndrome. Bosn. J. Basic Med. Sci. 2017, 17, 47-53. [CrossRef]

83. De Luca Canto, G.; Pacheco-Pereira, C.; Aydinoz, S.; Major, P.W.; Flores-Mir, C.; Gozal, D. Diagnostic capability of biological markers in assessment of obstructive sleep apnea: A systematic review and meta-analysis. J. Clin. Sleep Med. 2015, 11, 27-36. [CrossRef] [PubMed]

84. De Luca Canto, G.; Pacheco-Pereira, C.; Aydinoz, S.; Major, P.W.; Flores-Mir, C.; Gozal, D. Biomarkers associated with obstructive sleep apnea: A scoping re- view. Sleep Med. Rev. 2014, 23C, $28-45$.

85. Park, C.S.; Guilleminault, C.; Park, H.J.; Cho, J.H.; Lee, H.K.; Son, H.L.; Hwang, S.H. Correlation of salivary alpha amylase level and adenotonsillar hypertrophy with sleep disordered breathing in pediatric subjects. J. Clin. Sleep Med. 2014, 10, 559-566. [CrossRef] [PubMed]

86. Gozal, D.; Jortani, S.; Snow, A.B.; Kheirandish-Gozal, L.; Bhattacharjee, R.; Kim, J.; Capdevila, O.S. Two-dimensional differential in-gel electrophoresis proteomic approaches reveal urine candidate biomarkers in pediatric obstructive sleep apnea. Am. J. Respir. Crit. Care Med. 2009, 180, 1253-1261. [CrossRef] [PubMed]

87. Villa, M.P.; Supino, M.C.; Fedeli, S.; Rabasco, J.; Vitelli, O.; Del Pozzo, M.; Gentile, G.; Lionetto, L.; Barreto, M.; Simmaco, M. Urinary concentration of 8-isoprostane as marker of severity of pediatric OSAS. Sleep Breath 2014, 18, 723-729. [CrossRef] [PubMed] 
88. Kaditis, A.G.; Alexopoulos, E.; Chaidas, K.; Ntamagka, G.; Karathanasi, A.; Tsilioni, I.; Kiropoulos, T.S.; Zintzaras, E.; Gourgoulianis, K. Urine concentrations of cysteinyl leukotrienes in children with obstructive sleep-disordered breathing. Chest 2009, 135, 1496-1501. [CrossRef] [PubMed]

89. Magliulo, G.; Iannella, G.; Polimeni, A.; De Vincentiis, M.; Meccariello, G.; Gulotta, G.; Pasquariello, B.; Montevecchi, F.; De Vito, A.; D’Agostino, G.; et al. Laryngopharyngeal reflux in obstructive sleep apnoea patients: Literature review and meta-analysis. Am. J. Otolaryngol. 2018, 39, 776-780. [CrossRef] [PubMed]

90. Kheirandish-Gozal, L.; Gileles-Hillel, A.; Alonso-Álvarez, M.L.; Peris, E.; Bhattacharjee, R.; Terán-Santos, J.; Duran-Cantolla, J.; Gozal, D. Effects of adenotonsillectomy on plasma inflammatory biomarkers in obese children with obstructive sleep apnea: A community-based study. Int. J. Obes. 2015, 39, 1094-1100. [CrossRef]

91. Katz, E.S.; D'Ambrosio, C.M. Pediatric obstructive sleep apnea syndrome. Clin. Chest Med. 2010, 31, 221-234. [CrossRef]

92. Nisbet, L.C.; Yiallourou, S.R.; Walter, L.M.; Horne, R.S. Blood pressure regulation, autonomic control and sleep disordered breathing in children. Sleep Med. Rev. 2014, 18, 179-189. [CrossRef]

93. Beebe, D.W. Neurobehavioral morbidity associated with disordered breathing during sleep in children: A comprehensive review. Sleep 2006, 29, 1115-1134. [CrossRef] [PubMed]

94. Beebe, D.W.; Rausch, J.; Byars, K.C.; Lanphear, B.; Yolton, K. Persistent snoring in preschool children: Predictors and behavioral and developmental correlates. Pediatrics 2012, 130, 382-389. [CrossRef] [PubMed]

95. Abman, S.H.; Ivy, D.D. Recent progress in understanding pediatric pulmonary hypertension. Curr. Opin. Pediatr. 2011, 23, 298-304. [CrossRef] [PubMed]

96. Ingram, D.G.; Matthews, C.K. Effect of adenotonsillectomy on c-reactive protein levels in children with obstructive sleep apnea: A meta-analysis. Sleep Med. 2013, 14, 172-176. [CrossRef] [PubMed]

97. O’Brien, L.M.; Serpero, L.D.; Tauman, R.; Gozal, D. Plasma adhesion molecules in children with sleep-disordered breathing. Chest 2006, 129, 947-953. [CrossRef]

98. Kim, J.; Bhattacharjee, R.; Snow, A.B.; Capdevila, O.S.; Kheirandish-Gozal, L.; Gozal, D. Myeloid-related protein 8/14 levels in children with obstructive sleep apnoea. Eur. Respir. J. 2010, 35, 843-850. [CrossRef] [PubMed]

99. Bhushan, B.; Khalyfa, A.; Spruyt, K.; Kheirandish-Gozal, L.; Capdevila, O.S.; Bhattacharjee, R.; Kim, J.; Keating, B.; Hakonarson, H.; Gozal, D. Fatty-acid binding protein 4 gene polymorphisms and plasma levels in children with obstructive sleep apnea. Sleep Med. 2011, 12, 666-671. [CrossRef]

100. Kaditis, A.G.; Alexopoulos, E.I.; Damani, E.; Karadonta, I.; Kostadima, E.; Tsolakidou, A.; Gourgoulianis, K.; Syrogiannopoulos, G.A. Obstructive sleep-disordered breathing and fasting insulin levels in nonobese children. Pediatr. Pulmonol. 2005, 40, 515-523. [CrossRef]

101. Lesser, D.J.; Bhatia, R.; Tran, W.H.; Oliveira, F.; Ortega, R.; Keens, T.G.; Mittelman, S.D.; Khoo, M.C.; Davidson Ward, S.L. Sleep fragmentation and intermittent hypoxemia are associated with decreased insulin sensitivity in obese adolescent Latino males. Pediatr. Res. 2012, 72, 293-298. [CrossRef]

102. Chervin, R.D.; Hedger, K.; Dillon, J.E.; Pituch, K.J. Pediatric sleep questionnaire (PSQ): Validity and reliability of scales for sleep-disordered breathing, snoring, sleepiness, and behavioural problems. Sleep Med. 2000, 1, 21-32. [CrossRef]

103. Villa, M.P.; Paolino, M.C.; Castaldo, R.; Vanacore, N.; Rizzoli, A.; Miano, S.; Del Pozzo, M.; Montesano, M. Sleep Clinical Record: an aid to rapid and accurate diagnosis of Paediatric Sleep Disordered Breathing. Eur. Respir. J. 2013, 41, 1355-1361. [CrossRef] [PubMed]

104. Borgstrom, A.; Nerfeldt, P.; Friberg, D. Questionnaire OSA-18 has poor validity compared to polysomnography in pediatric obstructive sleep apnea. Int. J. Pediatr. Otorhinolaryngol. 2013, 77, 1864-1868. [CrossRef] [PubMed]

105. Kadmon, G.; Chung, S.A.; Shapiro, C.M. I'M SLEEPY: A short pediatric sleep apnea questionnaire. Int. J. Pediatr. Otorhinolaryngol. 2014, 78, 2116-2120. [CrossRef] [PubMed]

106. Moore, S. A pediatric 'sleep formula' and 'red flag' system. In Proceedings of the AAMS (Academy of Applied Myofunctional Sciences) poster session, Rome, Italy, 5-10 September 2018.

107. Burghard, M.; Brożek-Mądry, E.; Krzeski, A. Sleep disordered breathing in children-Diagnostic questionnaires, comparative analysis. Int. J. Pediatr. Otorhinolaryngol. 2019, 120, 108-111. [CrossRef] [PubMed]

108. Brooks, L.J.; Stephens, B.M.; Bacevice, A.M. Adenoid size is related to severity but not the number of episodes of obstructive apnea in children. J. Pediatr. 1998, 132, 682-686. [CrossRef] 
109. Lam, Y.Y.; Chan, E.Y.; Ng, D.K.; Chan, C.H.; Cheung, J.M.; Leung, S.Y.; Chow, P.Y.; Kwok, K.L. The correlation among obesity, apnea-hypopnea index, and tonsil size in children. Chest 2006, 130, 1751-1756. [CrossRef] [PubMed]

110. Goldberg, S.; Shatz, A.; Picard, E.; Wexler, I.; Schwartz, S.; Swed, E.; Zilber, L.; Kerem, E. Endoscopic findings in children with obstructive sleep apnea: Effects of age and hypotonia. Pediatr. Pulmonol. 2005, 40, 205-210. [CrossRef]

111. Zettergren-Wijk, L.; Forsberg, C.M.; Linder-Aronson, S. Changes in dentofacial morphology after adeno-/ tonsillectomy in young children with obstructive sleep apnoea-a 5-year follow-up study. Eur. J. Orthod. 2006, 28, 319-326. [CrossRef]

112. Kirk, V.G.; Bohn, S.G.; Flemons, W.W.; Remmers, J.E. Comparison of home oximetry monitoring with laboratory polysomnography in children. Chest 2003, 124, 1702-1708. [CrossRef]

113. Scholle, S.; Scholle, H.C.; Kemper, A.; Glaser, S.; Rieger, B.; Kemper, G.; Zwacka, G. First night effect in children and adolescents undergoing polysomnography for sleepdisordered breathing. Clin. Neurophysiol. 2003, 114, 2138-2145. [CrossRef]

114. Zucconi, M.; Calori, G.; Castronovo, V.; Ferini-Strambi, L. Respiratory monitoring by means of an unattended device in children with suspected uncomplicated obstructive sleep apnea: A validation study. Chest 2003, 124, 602-607. [CrossRef] [PubMed]

115. Goodwin, J.L.; Enright, P.L.; Kaemingk, K.L.; Rosen, G.M.; Morgan, W.J.; Fregosi, R.F.; Quan, S.F. Feasibility of using unattended polysomnography in children for research report of the Tucson Children's Assessment of Sleep Apnea study (TuCASA). Sleep 2001, 24, 937-944. [CrossRef] [PubMed]

116. Redline, S.; Budhiraja, R.; Kapur, V.; Marcus, C.L.; Mateika, J.H.; Mehra, R.; Parthasarthy, S.; Somers, V.K.; Strohl, K.P.; Sulit, L.G.; et al. The scoring of respiratory events in sleep: Reliability and validity. J. Clin. Sleep Med. 2007, 3, 169-200. [PubMed]

117. Katz, E.S.; Greene, M.G.; Carson, K.A.; Galster, P.; Loughlin, G.M.; Carroll, J.; Marcus, C.L. Night-to-night variability of polysomnography in children with suspected obstructive sleep apnea. J. Pediatr. 2002, 140, 589-594. [CrossRef] [PubMed]

118. Li, A.M.; Wing, Y.K.; Cheung, A.; Chan, D.; Ho, C.; Hui, S.; Fok, T.F. Is a 2-night polysomnographic study necessary in childhood sleep-related disordered breathing? Chest 2004, 126, 1467-1472. [CrossRef] [PubMed]

119. Aurora, R.N.; Zak, R.S.; Karippot, A.; Lamm, C.I.; Morgenthaler, T.I.; Auerbach, S.H.; Bista, S.R.; Casey, K.R.; Chowdhuri, S.; Kristo, D.A.; et al. Practice parameters for the respiratory indications for polysomnography in children. Sleep 2011, 34, 379-388. [CrossRef] [PubMed]

120. Chan, D.K.; Liming, B.J.; Horn, D.L.; Parikh, S.R. A new scoring system for upper airway pediatric sleep endoscopy. JAMA Otolaryngol. Head Neck Surg. 2014, 140, 595-602. [CrossRef]

121. Chen, J.; He, S. Drug-induced sleep endoscopy-directed adenotonsillectomy in pediatric obstructive sleep apnea with small tonsils. PLoS ONE 2019, 14, 0212317. [CrossRef]

122. Croft, C.B.; Pringle, M. Sleep nasendoscopy: A technique of assessment in snoring and obstructive sleep apnoea. Clin. Otolaryngol. Allied Sci. 1991, 16, 504-509. [CrossRef]

(C) 2019 by the authors. Licensee MDPI, Basel, Switzerland. This article is an open access article distributed under the terms and conditions of the Creative Commons Attribution (CC BY) license (http://creativecommons.org/licenses/by/4.0/). 